\title{
Optimisasi dan pemurnian IAA yang dihasilkan Rhizobium sp. dalam medium serum lateks dengan suplementasi triptofan dari pupuk kandang
}

\author{
Optimization and purification of IAA produced by Rhizobium sp. in latex serum media \\ supplemented with tryptophan from chicken manure \\ Irma KRESNAWATY ${ }^{1)}$, Syeda ANDANAWARIH ${ }^{2)}$, \\ SUHARYANTO ${ }^{1)}$ \& TRI-PANJI ${ }^{1)} *$ ) \\ ${ }^{1)}$ Balai Penelitian Bioteknologi Perkebunan, Bogor 16151, Indonesia \\ ${ }^{2)}$ Departemen Biokimia, Fakultas MIPA, Institut Pertanian Bogor, Indonesia
}

\begin{abstract}
Summary
Concentrated latex effluent had not been economically utilized, consequently it had become source of environmental pollution and conflicts with surrounding community. Whereas, the concentrated latex effluent could be used as substrate for microbes growth media due to its high concentration of carbon and nitrogen. One of the economical benefits of growing Rhizobium sp. in this waste is the production of indole acetic acid (IAA) that can be used for plant promotion growth. The aims of this research were to get the optimal IAA production of Rhizobium sp. by optimizing its tryptophan supplementation through hydrolysis of chicken manure and to purify IAA produced using chromatographic method. The use of chicken manure directly caused the browning effect, therefore these experiments were carried out the variation of $\mathrm{NaOH} 2 \mathrm{~N}$ hydrolysis treatments to reduce the effect. Direct hydrolysis as the first media was obtained by mixing latex serum and manure, and then this mixture was hydrolyzed. Meanwhile, separated hydrolysis was done by adding water to manure, being hydrolyzed, and divided to become second and third media. The second media was made by mixing manure hydrolysate and latex serum directly, whereas in third media, hydrolisate was added with alum as coagulating agent. Rhizobium $s p$. was then inoculated to all media and incubated for

24, 48, and 72 hours in $27-30^{\circ}$ C. IAA was analyzed by spectrophotometric method with Salkowsky reagent and Thin Layer Chromatography (TLC). IAA was then extracted with ethyl acetate and purified with silica gel column chromatography. The separated hydrolysis without coagulation (second media) produced the highest IAA concentration, that is $14.40 \mu \mathrm{g} / \mathrm{mL}$, whereas IAA produced by direct hydrolysis (first media) was $14.13 \mu \mathrm{g} / \mathrm{mL}$ and $0.90 \mu \mathrm{g} / \mathrm{mL}$ for third media during 48 hours. The fractionation result for each mediums showed that the highest IAA distribution in first media was the $12^{\text {th }}$ fraction $(38.70 \%)$, meanwhile in second media was the $15^{\text {th }}$ fraction $(50.25 \%)$ and in the third media was the $13^{\text {th }}$ fraction (26.16\%).

[Keywords : IAA, Rhizobium sp, latex effluent, tryptophan, chicken manure]

\section{Ringkasan}

Limbah lateks pekat saat ini belum dimanfaatkan secara ekonomis, bahkan menjadi sumber pencemaran lingkungan dan konflik dengan masyarakat sekitarnya. Padahal limbah lateks pekat dapat digunakan sebagai substrat pertumbuhan mikroba karena memiliki kandungan karbon dan nitrogen yang cukup tinggi. Salah satu nilai ekonomis yang dapat 
diperoleh dengan ditumbuhkannya Rhizobium sp. pada limbah tersebut, yaitu dihasilkannya asam indol asetat (indol acetic acid/IAA) yang dapat digunakan untuk memacu pertumbuhan tanaman. Penelitian ini bertujuan memperoleh produksi IAA optimal yang dihasilkan Rhizobium sp. dengan asupan triptofan dari hidrolisis pupuk kandang dan memurnikan IAA yang dihasilkan tersebut dengan metode kromatografi. Penggunaan pupuk kandang secara langsung menyebabkan efek pencokelatan, maka dilakukan variasi perlakuan hidrolisis dengan $\mathrm{NaOH} 2 \mathrm{~N}$ untuk mengurangi efek tersebut. Hidrolisis langsung sebagai medium pertama diperoleh dengan mencampur serum lateks dan pupuk kandang, sedangkan hidrolisis terpisah dilakukan dengan menambah pupuk kandang dengan air, dan dibagi menjadi medium kedua dan ketiga. Medium kedua dibuat dengan cara langsung mencampur hidrolisat dan serum lateks, sedangkan pada medium ketiga, hidrolisat diendapkan dengan alum sebagai bahan pengendap. Kemudian ke dalam masingmasing medium diinokulasi Rhizobium sp. dan diinkubasi selama 24,48 , dan 72 jam pada suhu $27-30^{\circ} \mathrm{C}$. Analisis IAA dilakukan secara spektrofotometri dengan metode Salkowski dan Kromatografi Lapis Tipis (KLT). IAA diekstraksi menggunakan etil asetat dan dimurnikan dengan kromatografi kolom silika gel. Hidrolisis terpisah tanpa pengendapan (medium kedua) menghasilkan IAA tertinggi, yaitu $14,40 \mu \mathrm{g} / \mathrm{mL}$, sedangkan hidrolis langsung (medium pertama) menghasilkan IAA sebesar $14,13 \mu \mathrm{g} / \mathrm{mL}$ dan medium ketiga sebesar $0,90 \mu \mathrm{g} / \mathrm{mL}$ selama 48 jam. Hasil fraksinasi untuk masing-masing medium menunjukkan sebaran IAA tertinggi pada medium pertama berada pada fraksi ke-12 $(38,70 \%)$, sedangkan pada medium kedua pada fraksi ke-15 $(50,25 \%)$, dan pada medium ketiga ialah fraksi ke-13 (26,16\%).

\section{Pendahuluan}

Limbah cair pengolahan lateks pekat yang berupa serum lateks skim memiliki nilai COD lebih dari 25.000 ppm dan kandungan nitrogen total lebih dari 4.000 ppm yang menjadi sumber pencemaran lingkungan dan konflik dengan masyarakat di sekitar pabrik pengolahan lateks (Tri Panji et al., 1995). Kandungan karbon dan nitrogen yang tinggi dalam limbah cair lateks pekat dapat digunakan oleh mikroba penghasil asam indol asetat (indole acetic acid/IAA) sebagai substrat pertumbuhan, sehingga meningkatkan nilai tambah limbah tersebut.

IAA termasuk fitohormon golongan auksin alami dan berperan sebagai zat pemacu pertumbuhan tanaman karena dapat meningkatkan sintesis DNA dan RNA, serta meningkatkan pertukaran proton (Aslamsyah, 2002). Biosintesis IAA oleh mikroba dapat ditingkatkan dengan penambahan triptofan eksogenus sebagai prekursor (Arshad et al. dalam Arkhipchenko, 2004). Penelitian Gusnaniar (2007) membuktikan bahwa bakteri tanah yang memproduksi IAA tertinggi ialah Rhizobium sp. sebesar $51,08 \mu \mathrm{g} / \mathrm{mL}$ dengan menambahkan asam amino L-triptofan sebagai prekursor. Karena tingginya harga triptofan komersial, diperlukan eksplorasi sumber triptofan alami yang tersedia dalam jumlah banyak dan mudah diperoleh, serta relatif murah. Salah satu sumber triptofan yang ekonomis ialah pupuk kandang. Menurut Arkhipchenco et al. (2006), limbah kotoran ayam mengandung triptofan sebesar 460,1 $\pm 5,9 \mu \mathrm{g} / \mathrm{g}$.

Hasil penelitian Gusnaniar (2007) menunjukkan bahwa produksi IAA menggunakan serum lateks dengan suplementasi triptofan langsung dari pupuk kandang masih rendah karena triptofan masih terikat dengan asam amino lain, sehingga tidak dapat digunakan sebagai prekursor produksi IAA. Di samping itu juga menyebabkan warna cokelat akibat reaksi 
Optimisasi dan pemurnian IAA yang dihasilkan Rhizobium $s p . .$.

browning non enzimatis yang mengganggu pembacaan absorban pada penentuan konsentrasi IAA. Karena itu, perlu pemecahan protein pada pupuk kandang menjadi bentuk asam amino bebas dengan cara hidrolisis. Efek browning dapat dikurangi dengan cara hidrolisis tidak langsung, sehingga kesalahan pembacaan absorban dalam analisis IAA dapat ditekan. Penelitian ini bertujuan menetapkan kondisi optimum produksi IAA oleh Rhizobium sp. dengan mengatur asupan triptofan dari pupuk kandang dengan variasi perlakuan hidrolisis dan mengisolasi IAA, serta memurnikan IAA dari medium serum lateks untuk mendapatkan IAA yang relatif murni.

\section{Bahan dan Metode}

\section{Bahan}

Serum lateks pekat Hevea brasiliensis hasil penggumpalan spontan diperoleh dari Kebun Jalupang PTPN VIII- Subang, kotoran ayam kering (pupuk kandang), dan kultur Rhizobium sp. R6 koleksi BPBPI Bogor.

\section{Penyiapan inokulum}

Rhizobium sp. R6 dikulturkan dalam medium cair Yeast Extract Mannitol (YEM) yang mengandung $0,125 \mathrm{~g}$ $\mathrm{K}_{2} \mathrm{HPO}_{4} ; 0,05 \mathrm{~g} \mathrm{MgSO}_{4} ; 0,025 \mathrm{~g} \mathrm{NaCl}$; $0,25 \mathrm{~g}$ yeast extract, $5 \mathrm{~g}$ agar-agar, $250 \mathrm{~mL}$ akuades, dan 2,5 g glukosa (Rao, 1981) dan diinkubasi pada suhu $27-30^{\circ} \mathrm{C}$ selama tiga hari. Suspensi Rhizobium sp.. dalam medium digunakan sebagai inokulum sebanyak 5\% v/v pada hidrolisis langsung dan tidak langsung.

\section{Hidrolisis protein pupuk kandang}

Triptofan sebagai prekursor IAA diperoleh dari hidrolisis protein pupuk kandang menggunakan basa kuat. Hidrolisis langsung dilakukan dengan mereaksikan sebanyak 37,5 g pupuk kandang dan $40 \mathrm{~g} \mathrm{NaOH}$ yang langsung dicampurkan dalam $500 \mathrm{~mL}$ serum lateks. Campuran dipanaskan pada suhu $100^{\circ} \mathrm{C}$ selama empat jam lalu disaring menggunakan kapas dan kain kasa. Filtrat dikumpulkan dan digunakan sebagai medium kesatu untuk pertumbuhan Rhizobium sp. Hidrolisis tak langsung dilakukan dengan mereaksikan sebanyak 75 g pupuk kandang ditambah $100 \mathrm{~mL}$ air dan $8 \mathrm{~g} \mathrm{NaOH}$ dan dipanaskan pada suhu $100^{\circ} \mathrm{C}$ selama empat jam lalu disaring, kemudian larutan dibagi dua. Filtrat yang pertama digunakan sebagai medium kedua untuk pertumbuhan Rhizobium sp. dengan dicampurkan ke dalam $500 \mathrm{~mL}$ serum lateks. Filtrat kedua, digunakan untuk medium ketiga. Filtrat tersebut ditambah senyawaan alum (K2SO4.A12(SO4)3.24 $\mathrm{H} 2 \mathrm{O}) \quad 0,5 \% \mathrm{~b} / \mathrm{v}$, lalu supernatan hasil pengendapan dicampurkan ke dalam $500 \mathrm{~mL}$ serum lateks.

Larutan dari ketiga medium tersebut masing-masing ditambahkan $0,5 \mathrm{~mL} \mathrm{Cu}^{2+}$ dan $\mathrm{Zn}^{2+}$ 0,05 $\mathrm{mM}$ untuk stimulasi biosintesis IAA (Bhattacharyya \& Pati, 2000), $\mathrm{pH}$ diukur dan dinetralkan hingga menunjukkan kisaran 6,3-6,4 dan ditepatkan hingga $1 \mathrm{~L}$ dan disterilisasi dengan outoklaf pada suhu $121^{\circ} \mathrm{C}$ tekanan $1,2 \mathrm{~kg} / \mathrm{cm}^{2}$. Ketiga medium selanjutnya disebut medium serum lateks. Ke dalam masing-masing medium dimasukkan suspensi inokulum Rhizobium sp. sebanyak $5 \% \mathrm{v} / \mathrm{v}$ dan diguncang di atas shaker dalam suhu $27-30^{\circ} \mathrm{C}$. 
Analisis kuantitatif dan identifikasi IAA

Produksi IAA diukur secara spektrofotometri pada jam ke-24, 48, dan 72 jam. Sebanyak $5 \mathrm{~mL}$ sampel masing-masing medium ditambahkan asam trikloro asetat (TCA) $10 \%$ untuk menjernihkan larutan dan dibiarkan beberapa menit. Sebanyak masing-masing $1 \mathrm{~mL}$ supernatan hasil pengendapan digunakan untuk pengukuran konsentrasi IAA.

Analisis spektrofotometri dilakukan dengan metode Salkowski (Fletcher \& Saul, 1963). Sebanyak $2 \mathrm{~mL}$ suspensi dalam medium fermentasi diambil lalu disentrifugasi pada $11.000 \mathrm{rpm}$ selama 10 menit. Supernatannya sebanyak $1 \mathrm{~mL}$ ditambah $2 \mathrm{~mL}$ pereaksi Salkowski. Larutan lalu ditambah akuades hingga volumenya $6 \mathrm{~mL}$, dihomogenkan dengan vortex, didiamkan selama 30 menit untuk pengembangan warna, kemudian diukur absorbannya pada panjang gelombang $530 \mathrm{~nm}$. Serapan IAA dibaca dengan mengurangi nilai absorban sampel yang ditambah reagen Salkowski dengan nilai densitas optik sebelumnya.

Identifikasi IAA dengan metode kromatografi lapis tipis (KLT) dilakukan dengan meneteskan $10 \mu \mathrm{L}$ kultur di atas lempeng silika gel 60 F 254 panjang $20 \mathrm{~cm}$ dan lebar $10 \mathrm{~cm}$ dengan jarak $1 \mathrm{~cm}$. Setelah dikeringkan pada suhu ruang, lempeng dimasukkan dalam chamber KLT yang telah diisi eluen etil asetat: kloroform : asam format $(55: 35: 10 \mathrm{v} / \mathrm{v})$. Elusi dilakukan hingga eluen mencapai garis batas yang ditentukan. Lempeng dikeringkan pada suhu ruang dan noda dilihat pada sinar UV $366 \mathrm{~nm}$ (Gusnaniar, 2007). Hasil noda disesuaikan dengan standar Rf IAA.

\section{Ekstraksi IAA}

Sebanyak $40 \mathrm{~mL}$ medium serum lateks disentrifugasi dengan kecepatan $10.000 \mathrm{rpm}$ selama 30 menit. Supernatan diasamkan dengan $\mathrm{HCl} 1 \mathrm{~N}$ hingga $\mathrm{pH}$ akhir 2,5-3,0 kemudian diekstraksi dengan etil asetat dua kali. Lapisan etil asetat tersebut lalu diuapkan dengan rotary evaporator pada suhu $40{ }^{\circ} \mathrm{C}$ (Ahmad et al., 2004).

\section{Pemurnian IAA}

Sebanyak $10 \mathrm{~mL}$ fraksi etil asetat hasil ekstraksi IAA dimasukkan dalam kolom kromatografi padat cair. Tinggi kolom $20 \mathrm{~cm}$ dan diameter $2,5 \mathrm{~cm}$. Fase diamnya adalah silika gel. Sebanyak $8 \mathrm{~g}$ silika gel ditimbang dan disuspensikan dengan eluen lalu dituang dengan pipet secara hati-hati agar tidak terbentuk rongga udara. Tinggi fase diam $10 \mathrm{~cm}$ dan eluen yang digunakan terdiri atas etil asetat : kloroform : asam format $=7: 2: 1$ (v/v). Setiap $2 \mathrm{~mL}$ eluat yang keluar ditampung, setelah sampel habis lalu dilakukan KLT dan diuji konsentrasi IAA. Eluat lalu ditambah reagen Salkowski dan diukur absorbannya pada panjang gelombang $530 \mathrm{~nm}$. Konsentrasi IAA diperoleh dengan memasukkan nilai absorban pada kurva standar (Rubio et al., 2000).

\section{Hasil dan Pembahasan}

\section{Optimisasi produksi IAA}

Triptofan yang terkandung pada kotoran ayam masih berada dalam bentuk polipeptida, sehingga untuk memperoleh konsentrasi triptofan yang tinggi diperlu- 
Optimisasi dan pemurnian IAA yang dihasilkan Rhizobium sp....

kan hidrolisis untuk menjadi bentuk monomer bebas. Hidrolisis yang digunakan adalah hidrolisis basa dan menyebabkan semua asam amino yang dihasilkan rusak kecuali triptofan, sehingga hidrolisis ini spesifik untuk triptofan yang dibutuhkan sebagai prekursor IAA (AOAC, 1999).

Produksi IAA pada ketiga medium (Gambar 1) menunjukkan bahwa pada inkubasi selama 24 jam, IAA yang dihasilkan Rhizobium sp. ialah sebagai berikut: $6,73 \mu \mathrm{g} / \mathrm{mL}$ pada medium pertama, $\quad 7,42 \mu \mathrm{g} / \mathrm{mL}$ pada medium kedua, dan $0,39 \mu \mathrm{g} / \mathrm{mL}$ pada medium ketiga. Produksi IAA pada 48 jam mengalami peningkatan, yaitu: 14,13 ; 14,40 ; dan $0,90 \mu \mathrm{g} / \mathrm{mL}$ untuk masingmasing medium. Sedangkan produksi IAA pada 72 jam mengalami penurunan menjadi sebesar: 2,62; 1,38; dan $0,73 \mu \mathrm{g} / \mathrm{mL}$ berturut-turut untuk medium kesatu, kedua dan ketiga. Hasil uji Duncan $(\mathrm{p}<0,05)$ membuktikan antara medium kesatu dan kedua tidak berbeda nyata. Hal tersebut menunjukkan bahwa produksi IAA tidak berpengaruh pada cara hidrolisis baik langsung maupun terpisah. Hasil uji Duncan $(\mathrm{p}<0,05)$ medium kesatu dan kedua terhadap medium ketiga adalah berbeda nyata. Hal tersebut menunjukkan bahwa penambahan alum berpengaruh terhadap produksi IAA dalam hal ini menyebabkan penurunan produksi IAA Rhizobium sp.. Kadar logam yang tinggi akibat penambahan alum diindikasikan menginhibisi enzim-enzim pada Rhizobium sp. sehingga mengurangi produksi IAA. Selain itu juga diindikasikan bahwa sebagian triptofan ikut terendapkan akibat penambahan alum.

Produksi IAA tertinggi diperoleh pada waktu inkubasi selama 48 jam. Hal tersebut sesuai dengan hasil penelitian Gusnaniar (2007) yang menyatakan produksi IAA oleh Rhizobium sp. R6 tertinggi terjadi pada waktu inkubasi 48 jam. Pada periode inkubasi 48 jam Rhizobium sp. R6 memasuki fase akhir logaritmik, sehingga IAA yang dihasilkan cukup tinggi. Konsentrasi IAA yang dihasilkan masih lebih rendah dari yang dihasilkan menggunakan triptofan sintetik yang dilakukan oleh Gusnaniar (2007). Hal ini dapat disebabkan karena triptofan yang dihasilkan dari hidrolisis kotoran ayam memiliki kadar dan tingkat kemurnian yang masih rendah.

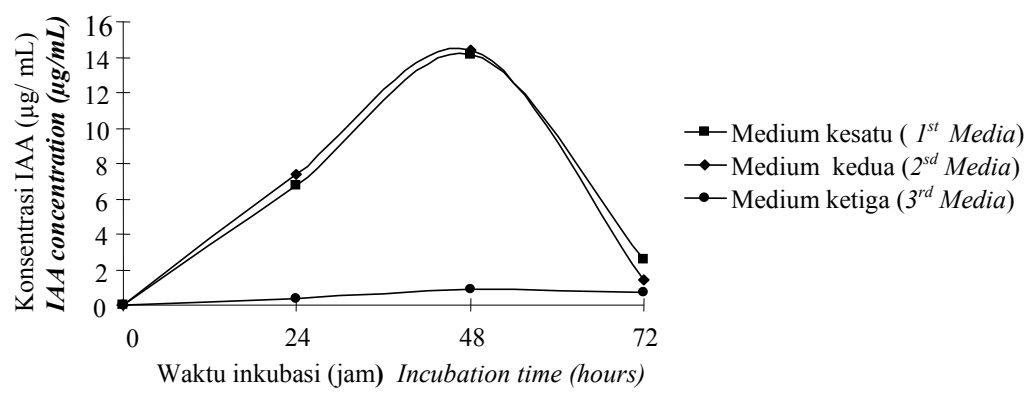

Gambar 1. IAA yang dihasilkan oleh Rhizobium sp. dalam medium kesatu, kedua dan ketiga.

Figure 1. IAA produced by Rhizobium sp.in the first, second and third media. 
Kresnawaty et al.

Hasil uji statistik konsentrasi IAA yang dihasilkan terhadap masing-masing waktu inkubasi 24, 48, dan 72 jam menunjukkan perbedaan yang nyata. Pada 24 jam, IAA yang dihasilkan lebih sedikit karena masih berada dalam fase logaritmik dan juga kandungan enzim-enzim untuk mengubah triptofan menjadi IAA masih rendah. Sedangkan pada waktu inkubasi 48 jam, IAA yang dihasilkan paling tinggi karena Rhizobium sp. berada pada fase akhir logaritmik dan kandungan enzimenzim yang digunakan dalam biokonversi triptofan menjadi IAA, seperti triptofan monooksigenase, IAM hidrolase, indolpiruvat dekarboksilase dan IAAld dehidrogenase, dihasilkan cukup banyak dan aktif sejalan dengan laju pertumbuhan. Pada waktu inkubasi 72 jam Rhizobium sp. telah memasuki fase kematian, sehingga produksi IAA menurun tajam. Menurut Bhattacharyya \& Basu dalam Sridevi \& Mallailah (2007) menyatakan bahwa penurunan produksi IAA pada 72 jam karena adanya pelepasan enzim pendegradasi IAA seperti IAA oksidase dan peroksidase.

Pembacaan absorban pada ketiga medium cukup sulit akibat reaksi pencokelatan, untuk itu dilakukan penambahan TCA yang dapat mengendapkan makromolekul seperti protein, DNA, RNA dalam serum lateks. Penambahan pereaksi Salkowski berwarna kuning muda menghasilkan warna merah kecokelatan yang menunjukkan adanya IAA (Gambar 2).

Produksi IAA tertinggi terdapat pada medium kedua dengan hidrolisis yang terpisah sebesar $14,40 \mu \mathrm{g} / \mathrm{mL}$. Hal tersebut disebabkan dalam hidrolisis terpisah, kandungan serum lateks yang digunakan untuk pertumbuhan Rhizobium sp. tidak mengalami kerusakan akibat hidrolisis dalam $\mathrm{NaOH}$ pada suhu tinggi, sehingga dapat digunakan secara optimal

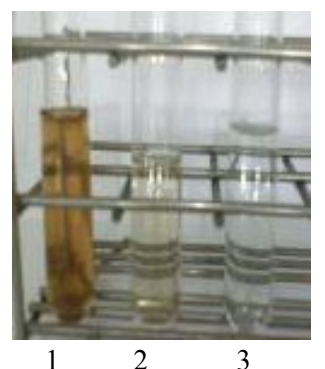

Gambar 2. Warna medium setelah penambahan TCA. 1) Ditambahkan reagen Salkowski, 2) Sebelum ditambahkan Salkowski dan 3) TCA.

Figure 2. The colour of media : 1) After addition of Salkowski reagent, 2) Before addition of Salkowski reagent, and 3) TCA.

oleh Rhizobium sp. sebagai sumber nutrisi untuk tumbuh dan berkembang. Berbeda dengan medium kesatu yang langsung mengalami hidrolisis sehingga kandungan serum lateks tersebut mengalami kerusakan sebelum digunakan oleh Rhizobium sp..

\section{Ekstraksi dan pemurnian IAA}

Ekstraksi IAA dalam serum lateks menggunakan pelarut semipolar etil asetat dipilih dengan alasan murah, aman penggunaannya, dan memiliki struktur yang mirip dengan IAA, yaitu adanya gugus asetat, sehingga dapat melarutkan IAA (like dissolved like). Pendeteksian IAA dilakukan secara kualitatif menggunakan KLT. Medium sebelum ekstraksi memiliki Rf yang tidak sejajar dengan standar IAA (Gambar 3). Hal tersebut disebabkan medium masih tercampur dengan pengotor yang lain sehingga sedikit meningkatkan kepolaran IAA. Setelah diekstraksi, noda pada masing-masing medium (S1, S2 dan $\mathrm{S} 3$ ) sejajar dengan standar (Std) nilai $\mathrm{R}_{\mathrm{f}} 0,44$. 


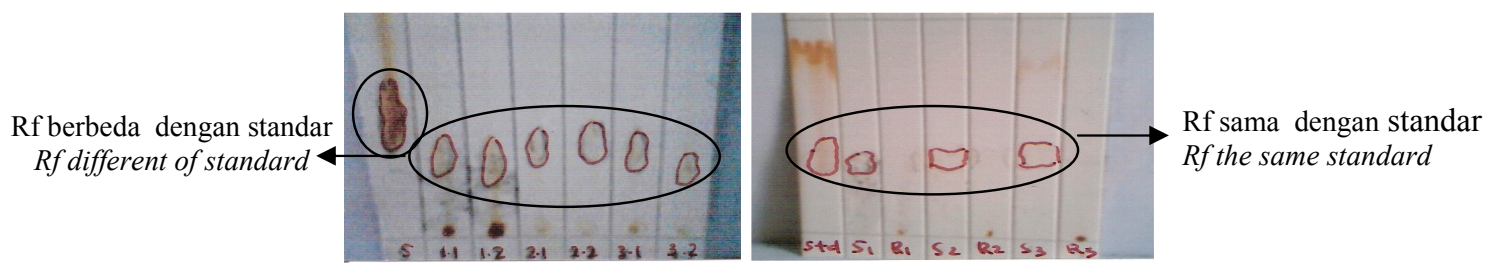

Gambar 3. Noda hasil KLT IAA sebelum ekstraksi (kiri), setelah ekstraksi dengan etil asetat (kanan.)

Figure 3. TLC of IAA spots before extraction (left), after extraction using ethyl acetate(right).

Menurut Kuraishi \& Muir (1963), $\mathrm{R}_{\mathrm{f}}$ IAA berada di antara 0,4 hingga 0,5 . Residu hasil ekstraksi juga dilakukan KLT untuk mengetahui masih terdapat IAA dalam residu atau tidak. Hasil KLT membuktikan dalam residu (R1,R2 dan R3) tidak terkandung IAA karena tidak terdapat noda (Gambar 3). Pemisahan menggunakan etil asetat menghasilkan senyawa IAA yang lebih murni dan ditandai dengan makin berkurangnya tailing akibat adanya pengotor lain yang terlalut dalam medium sebelum terekstraksi.

Pemurnian IAA dilakukan menggunakan kromatografi kolom silika gel dengan pelarut etil asetat: kloroform : asam format $=7: 2: 1(\mathrm{v} / \mathrm{v})$. Dari hasil fraksinasi medium kesatu diperoleh 12 fraksi dengan fraksi yang mengandung IAA pada fraksi 10, 11, dan 12 dengan jumlah $1,53 \mu \mathrm{g} / \mathrm{mL}$ $(27,97 \%) ; 1,82 \mu \mathrm{g} / \mathrm{mL} \quad(33,33 \%)$; dan $2,12 \mu \mathrm{g} / \mathrm{mL}(38,70 \%)$ ( Gambar 4A). IAA terdeteksi pada fraksi 12 yang menunjukkan bahwa IAA masih terikat kuat pada gugus hidrofil pada silika gel dalam hal ini atom oksigen atau nitrogen pada IAA membentuk ikatan hidrogen dengan silika gel.

Fraksinasi medium kedua menghasilkan 15 fraksi (Gambar 4B) yang mengandung IAA ialah fraksi 13, 14, dan 15, yaitu masing-masing: $1,19 \mu \mathrm{g} / \mathrm{mL}$ $(26,75 \%) ; 1,03 \mu \mathrm{g} / \mathrm{mL} \quad(23,00 \%)$; dan
$2,24 \mu \mathrm{g} / \mathrm{mL}(50,25 \%)$. Noda yang dihasilkan berada pada fraksi 13, 14, dan 15 dengan nilai $R_{f}$, 44 yang sama dengan nilai $R_{f}$ standar IAA. Fraksi 1-12 tidak memunculkan noda, hal ini disebabkan material yang keluar masih berupa eluen. Fraksinasi medium ketiga menghasilkan 13 fraksi dan menunjukkan sebaran IAA yang bervariasi (Gambar 4C). Terbentuknya dua puncak diduga disebabkan adanya Difusi Eddie. Difusi Eddie muncul dari penggandaan lintasan untuk suatu aliran gas melalui suatu kolom yang berisi partikel-partikel dengan berbagai ukuran dan bentuk yang tidak beraturan. Besarnya kontribusi difusi Eddie dari pelebaran pita bergantung pada ukuran fasa diam, bentuk, dan keseragaman distribusi dalam kolom tersebut (Day \& Underwood, 1998). Fraksi yang memiliki kandungan IAA ialah fraksi 9, 10, 12 dan 13 dengan kandungan IAA berturut-turut ialah $1,86 \mu \mathrm{g} / \mathrm{mL} \quad(\quad 23,99 \%) ; 1,82 \mu \mathrm{g} / \mathrm{mL}$ $(23,45 \%), \quad 1,45 \mu \mathrm{g} / \mathrm{mL} \quad(18,59 \%)$; dan $2,03 \mu \mathrm{g} / \mathrm{mL}(26,16 \%)$.

Fraksi 9, 10, 12, dan 13 memiliki noda yang sejajar dengan standar IAA dengan nilai $R_{f} 0,44$ yang sama dengan nilai $R_{\mathrm{f}}$ standar IAA. Fraksi 11 memiliki nilai $R_{\mathrm{f}}$ yang lebih kecil dari standar sebesar 0,1875 yang menunjukkan bahwa dalam fraksi tersebut tidak terkandung IAA. 
Kresnawaty et al.
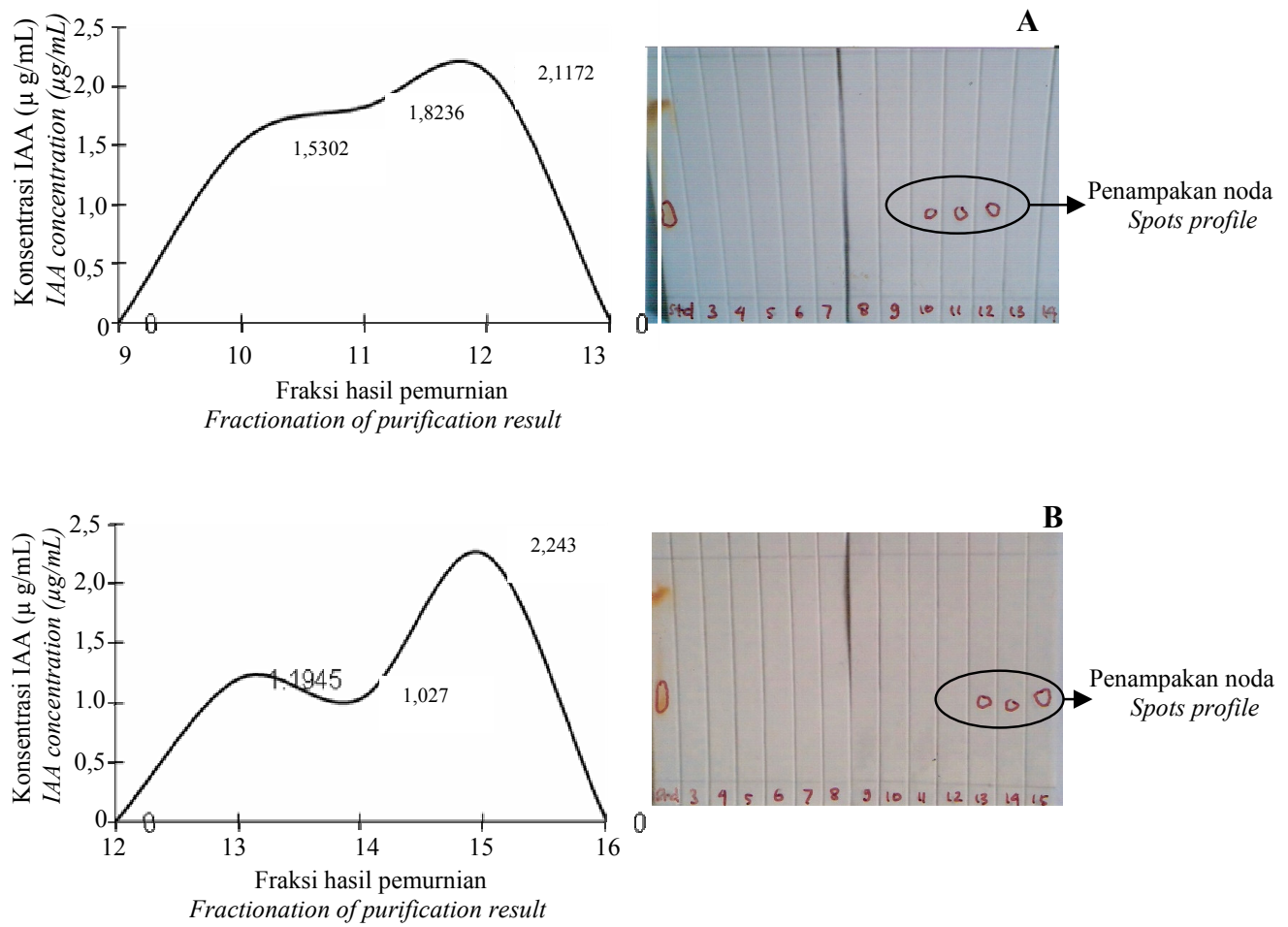

Fractionation of purification result
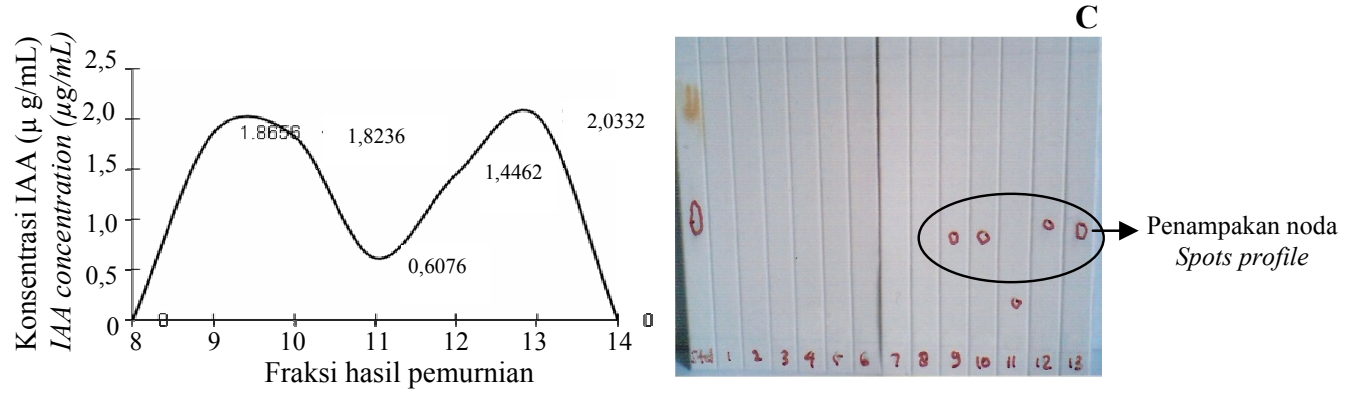

Fractionation of purification result

Gambar 4. Konsentrasi IAA dan penampakan noda fraksionasi medium kesatu (A), kedua (B) dan ketiga (C) hasil elusi dari kolom kromatografi.

Figure 4. The IAA concentration and spots profile of the first (A), second (B) and third medium (C) fractionation eluted from chromatographic column. 
Optimisasi dan pemurnian IAA yang dihasilkan Rhizobium sp....

\section{Kesimpulan}

Produksi IAA optimal dari Rhizobium sp. dalam medium serum lateks diperoleh dengan cara suplementasi pupuk kandang sebagai sumber triptofan yang dihidrolisis menggunakan $\mathrm{NaOH} 2 \mathrm{~N}$ yang dilakukan terpisah dengan serum lateks dan tanpa pengendapan menggunakan alum. Konsentrasi IAA yang diperoleh, yaitu sebesar $14,40 \mu \mathrm{g} / \mathrm{mL}$ pada medium kedua, sedangkan hidrolisis langsung (medium kesatu) menghasilkan IAA sebesar 14,13 $\mu \mathrm{g} / \mathrm{mL}$ dan medium ketiga sebesar $0,90 \mu \mathrm{g} / \mathrm{mL}$ selama 48 jam. IAA yang dihasilkan dapat diisolasi dengan cara ekstraksi dengan etil asetat dan fraksinasi dengan kolom kromatografi silika gel dengan eluen etil asetat : kloroform : asam format $=7: 2: 1(\mathrm{v} / \mathrm{v})$.

\section{Daftar Pustaka}

AOAC Official (1999). Analysis of AOAC International: Food Composition, Additive, Natural Contaminant. Ed ke-16, Vol 2. Maryland, Gaitunsburg. Bab 45, hlm 66.

Ahmad, F., I Ahmad \& M. S. Khan (2004). Indole acetic acid production by the indigenous isolates of Azotobacter and fluorescent Pseudomonas in the presence and absence of tryptofan. Turky J. Biol., 29, 29-34.

Arkhipchenko, I.A., Shaposhnikov A. I \& Kravcheno L.V. (2006). Triptophan concentration of animal waste and organic fertilizers. Elsevier. http:// www.science direct.com. [5 Feb 2008].

Aslamsyah, S. (2002). Peranan Hormon Tumbuh dalam Memacu Pertumbuhan Alga. http://tumoutou.net/702_05123/ siti aslamyah.htm. [15 Mar 2008].

Bhattacharyya, R. N. \& B.R Pati (2000). Growth behaviour and indole acetic acid (IAA) production by a Rhizobium isolated from root nodules of Alysicarpus vaginalis DC. Acta Microbiol. Immunology Hungaria, 47(1), 41-51.

Bhattacharyya, R. N. \& P. S. Basu (1990). Studies of the root nodules of leguminous plants IV: production of indole acetis acid Bradyrhizobium $s p$. from the root nodules of a legominous shrub, Crotalaria retusa L. Acta Biotechnol., 11, 439-447.

Day, R.A. \& A. L. Underwood (1998). Analisis Kimia Kuantitatif. Edisi ke-6. Jakarta, Universitas Indonesia Press.

Fletcher, R. A. \& Z. Saul (1963). Quantitative spectrophotometric determination of indol-3-acetic acid. Nature, 199, 903-904.

Gusnaniar (2007). Produksi IAA oleh Rhizobium spp, Pseudomonas spp, dan Azotobachter sp. dalam medium sintetik dan serum lateks Hevea brasiliensis Muel. Arg dengan suplementasi triptofan Skripsi. Yogyakarta, Fakultas Biologi, Universitas Gajah Mada.

Kuraishi, S. \& Muir R. M. (1963). Paper Chromatograpy Study of Diffusible Auxin. Tokyo, Biological Institute, University of Tokyo.

Rao, N.S.S. (1981). Biofetilizer in Agriculture. New Delhi, Oxford \& IBH Publ. CO.

Rubio, M.G.T, S.A.V Plata, J.B Castillo \& P.M Nieto (2000). Isolation of Enterobacteria, Azobacter sp, and Pseudomonas sp. producers of indole-3cetic acid and siderophores from Colombian Rice Rhizosphere. Revista Latinoamericana de Microbiologia 42,171-176.

Sridevi M \& K.V Mallailah (2007). Production of indole-3-acetic acid by Rhizobium isolates from Sesbania species. African J. Microbiol. Res., 1(7), 125-128.

Tri-Panji, Suharyanto, Erry Rakayan \& Hasim. (1995). Penggunaan serum lateks skim sebagai media produksi protein sel tunggal oleh Spirulina platensis, Menara Perkebunan, 63(3), 114-122. 